\title{
Construction of Attitude Scale for Attracting Rural Youth Towards Agri-Enterprises
}

\author{
Mubeena*, T. Lakshmi, P. L. R. J. Praveena, \\ A. V. Nagavani and B. Ramana Murthy \\ Acharya N G Ranga Agricultural University, Department of Agricultural Extension, S.V. \\ Agricultural College, Tirupati-517 502, India \\ *Corresponding author
}

A B S T R A C T

Keywords

Rural youth, Attitude scale, Statement wise analysis, Mean, Standard deviation

Article Info

Accepted:

21 May 2020

Available Online:

10 June 2020
The present research study was conducted during 2019-2020. In this study attitude of rural youth towards agri-enterprises was studied. Due to non-availability of appropriate scale to measure attitude of rural youth towards agri-enterprises, it was thought necessary to construct a scale for the purpose. Keeping this in view, an attempt has been made to develop a scale for measuring the attitude of rural youth towards agri-enterprises. Method of summated rating scale, by Likert (1932) was used. Thirty six statements were selected from fifty four statements for which ' $t$ ' values were worked out. Statements both positive and negative with $t$-values more than 1.75 for were selected. Statement wise content analysis of attitude of rural youth towards agri-enterprises was conducted. "I prefer to work with strong desire to achieve excellence in running the agri enterprise" with highest mean score (4.71) ranked first followed by "I prefer to be self-confident while taking decisions in running the agri-enterprise". In the same way remaining 34 statements were keenly analyzed and presented in the paper.

\section{Introduction}

Attitude is the prime cause for the growth of an individual and will have great impact on the way we think, the way we perceive and the way we do the things. It is the determining factor for the success or failure of any vibrant endeavor. As entrepreneurship is the most predominant avenue for the growth and development of a country, it became mandatory to strengthen the entrepreneurship through potential and dynamic rural youth of the country. Rural youth are a formidable force in the entrepreneurial sector.

While their contribution towards attaining food security cannot be under estimated, their lukewarm attitude towards agri-enterprise is a primary issue of concern and challenge to the future of the entrepreneurship in India. The attitude of youth towards agri-enterprises is the important concern to design deliberate 
strategies for attracting rural youth towards agripreneurship. Hence, there is need to study the attitude of rural youth towards agrienterprises. Edwards defined attitude as the degree of positive or negative affect associated with some psychological object. Attitude in this study was operationally defined as the degree of positive or negative feeling of rural youth towards agri-enterprise.

\section{Materials and Methods}

To measure the attitude of rural youth towards agri-enterprise, a scale has been developed by the following procedure. Method of summated rating scale, by Likert (1932) was used to construct the attitude scale of rural youth towards agri-enterprise.

\section{Steps used in construction of attitude scale are given below}

The following steps were carried out to construct the scale to measure the attitude of rural youth towards agripreneurship (Edwards, 1969 and Chandrakandan et al., 2000).

\section{Collection and editing of items}

A set of Fifty four statements representing the attitude of rural youth towards agripreneurship were collected initially from available literature and interaction with experts and then edited on the basis of criteria suggested by Thurstone and Chave (1929), Likert (1932) and Edwards (1957).

Out of fifty four statements, thirty six statements were retained after editing. These statements were administered to 88 judges having expertise in agri-enterprises. The respondents were asked to indicate their degree of agreement or disagreement with each statement on a five point continuum ranging from strongly agree to strongly disagree. A score of 5 was given to strongly agree response, 4 to agree response, 3 to undecided response, 2 to disagree response and 1 to strongly disagree response, for a positive statement and for negative statement, the scoring pattern was reversed viz., strongly disagree response with 1 weightage, agree with 2 , undecided with 3 , disagree with 4 and strongly disagree with 5 weightage in that order. Their responses were recorded and total score for each respondent was arrived by summing up the scores on all the statements.

The scores of the individual statements were summed up to get the total scores of the respondents. Based on the total scores obtained, the respondents were arranged in descending order. Then the top 25 per cent of the respondents with the highest scores and the bottom 25 per cent of the respondents with the lowest scores were considered as criterion groups to evaluate individual statements. The middle 50 per cent of the respondents were deleted for further analysis. The top 25 per cent were considered as high group and bottom 25 per cent were considered as low group to calculate the critical ratio i.e., ' $t$ ' value for each statement. The calculated ' $t$ ' value for each statement will measure the extent to which the statement differentiates between the respondents of high group and low group. The ' $t$ ' values were calculated by using the formula suggested by Edwards (1957). The ' $t$ ' value for each statement was calculated by using the formula.

$$
t=\frac{\left(\bar{X}_{H}-\bar{X}_{L}\right)}{\sqrt{\sum\left(X_{H}-\bar{X}_{H}\right)^{2}+\sum\left(X_{L}-\bar{X}_{L}\right)^{2} / n(n-1)}}
$$

where,

$\bar{X}_{H}=$ Mean score on a given statement for the high group

$\bar{X}_{L}=$ Mean score on a given statement for the low group 


$$
\begin{array}{ll}
\Sigma\left(X_{H}-\bar{X}_{H}\right)^{2} & =\Sigma X_{H}^{2}-\frac{\Sigma\left(X_{H}\right)^{2}}{n_{H}} \\
\Sigma\left(X_{L}-\bar{X}_{L}\right)^{2} & =\Sigma X_{L}^{2}-\frac{\Sigma\left(X_{L}\right)^{2}}{n_{L}} \\
\bar{X}_{H} & =\frac{\Sigma X_{H}}{n_{H}} \\
\bar{X}_{L} & =\frac{\Sigma X_{L}}{n_{L}} \\
n & =n_{L}=n_{H}
\end{array}
$$

Selection of attitude statements for final scale

After computing ' $t$ ' values for all the items (Table 1), statements comprising of twenty five positive and nine negative statements with $t$ value equal to or greater than 1.75 were finally selected and included in the attitude scale.

\section{Reliability of the scale}

A scale is reliable when it will consistently produce the same results when applied on the same sample (Goode and Hatt, 1952). For testing the reliability, split half method was employed. The attitude scale of 36 statements was distributed to thirty rural youth in agripreneurship of non-sample area for their responses. After getting back the responses, the scale was divided into two halves, all odd statements into one half and all even statements into another. Then the co-efficient of reliability was calculated between the two halves. The correlation coefficient for both the sets was worked out. The correlation coefficient $(\mathrm{r}=0.84)$ was significant at 0.01 level indicating the attitude scale was highly suitable for administration to the rural youth in agripreneurship.

\section{Validity of the scale}

\section{Content validity}

As the content of the attitude thoroughly covered the entire universe of the rural youth with special emphasis on agripreneurship

\begin{tabular}{|c|c|c|}
\hline S.No & Statements & $\begin{array}{l}\text { t values for } \\
\text { all } \\
\text { statements }\end{array}$ \\
\hline 1. & I feel rural youth need more trainings and technical support from Govt. / NGOs. & 0.169 \\
\hline 2. & $\begin{array}{l}\text { I feel subsidies and incentives provided by the Government for young } \\
\text { agripreneurs are not adequate and supporting (-) }\end{array}$ & 1.859* \\
\hline 3. & I feel having job either private/ public is better than starting enterprise (-) & $1.767^{*}$ \\
\hline 4. & $\begin{array}{l}\text { I feel agripreneurship is the only source of self-employment for rural youth to } \\
\text { arrest their migration to nearby cities. }\end{array}$ & 1.953* \\
\hline 5. & $\begin{array}{l}\text { I would like to give my ideas and take the other ideas for the benefit of agri- } \\
\text { enterprise. }\end{array}$ & $1.994 *$ \\
\hline 6. & $\begin{array}{l}\text { I want to become a role model for other agripreneurs by succeeding in my own } \\
\text { agri- enterprise. }\end{array}$ & 0.224 \\
\hline 7. & I feel an agripreneur should be self motivated in achieving his goals. & 0.447 \\
\hline 8. & I feel successful agripreneurs always tend to think ahead. & 1.988* \\
\hline 9. & $\begin{array}{l}\text { I feel success will not come without proper publicity and product promotion } \\
\text { in agripreneurship }\end{array}$ & $1.753 *$ \\
\hline
\end{tabular}
through available literature and consultation with expert opinion, it was assumed that present scale satisfied the content validity.

Table.1 Final scale administered to the respondents 


\begin{tabular}{|c|c|c|}
\hline 10. & $\begin{array}{l}\text { I feel identification of customer needs has nothing to do with agripreneurship } \\
(-)\end{array}$ & 2.903* \\
\hline 11. & I feel one must be prepared to take risk in agripreneurship & 1.818* \\
\hline 12. & $\begin{array}{l}\text { I feel feasibility study/project appraisal is of no help in grabbing opportunities in } \\
\text { agripreneurship (-) }\end{array}$ & 0.528 \\
\hline 13. & $\begin{array}{l}\text { I prefer to work with strong desire to achieve excellence in running the agri- } \\
\text { enterprise }\end{array}$ & 1.919* \\
\hline 14. & $\begin{array}{l}\text { I prefer not to exhibit independence in taking decisions regarding running the } \\
\text { agri enterprise (-) }\end{array}$ & $2.065 *$ \\
\hline 15. & I prefer to be diversified to avoid risk in running the agri- enterprise & 0.723 \\
\hline 16. & I prefer to act with positive self concept in running the agri- enterprise & 0.169 \\
\hline 17. & I prefer to be cosmopolitan in my work in running the agri- enterprise & 1.794* \\
\hline 18. & $\begin{array}{l}\text { I am a person easily discouraged by failures in the agr-i enterprise } \\
(-)\end{array}$ & 2.664* \\
\hline 19. & I prefer to grab the opportunity in successful running of the agri- enterprise & 2.449* \\
\hline 20. & $\begin{array}{l}\text { I prefer not to give importance for problem solving in running agri - } \\
\text { enterprise (-) }\end{array}$ & $2.536 *$ \\
\hline 21. & I prefer to confront uncertainities in running the agri- enterprise & 2.822* \\
\hline 22. & $\begin{array}{l}\text { I prefer little to negotiate with customers/buyers/contractors for securing } \\
\text { better price for the product in running the agri -enterprise }(-)\end{array}$ & 1.798* \\
\hline 23. & I prefer not to face stressful/crisis situation in running the agri- enterprise & 0.692 \\
\hline 24. & I prefer to give importance for time management in running the agri- enterprise (-) & 0.994 \\
\hline 25. & I prefer little to try innovative methods in running my agri- enterprise (-) & 0.522 \\
\hline 26. & $\begin{array}{l}\text { I prefer little to introduce new products/new methods /new markets in } \\
\text { running the agri- enterprise (-) }\end{array}$ & $2.261 *$ \\
\hline 27. & $\begin{array}{l}\text { I prefer to be selective in deciding course of action in running the agri- } \\
\text { enterprise }\end{array}$ & 1.788* \\
\hline 28. & $\begin{array}{l}\text { I prefer to develop necessary written } \& \text { oral communication skills in running } \\
\text { the agri-enterprise }\end{array}$ & 2.534* \\
\hline 29. & $\begin{array}{l}\text { I prefer to give importance to visionary outlook in running the agri- } \\
\text { enterprise }\end{array}$ & 2.347* \\
\hline 30. & $\begin{array}{l}\text { I prefer little to make effective utilization of resources in running the agri - } \\
\text { enterprise (-) }\end{array}$ & 1.216 \\
\hline 31. & $\begin{array}{l}\text { I prefer to know the cost of raw material for production in running the agri- } \\
\text { enterprise }\end{array}$ & $1.869 *$ \\
\hline 32. & $\begin{array}{l}\text { I prefer to be self confident while taking decisions in running the agri- } \\
\text { enterprise }\end{array}$ & 2.531* \\
\hline 33. & $\begin{array}{l}\text { I prefer to weigh profit making as measure of success in running the agri- } \\
\text { enterprise }\end{array}$ & 0.288 \\
\hline 34. & $\begin{array}{l}\text { I prefer little to carry out market survey for effective running of the agri enterprise } \\
(-)\end{array}$ & 0.623 \\
\hline 35. & I prefer to lay down the policies of recruitment in running the agri enterprise & 1.876* \\
\hline 36. & I prefer to get the project report prepared in running the agri-enterprise & 0.449 \\
\hline 37. & I prefer not to know the existing problems in running the agri-enterprise (-) & 1.873* \\
\hline 38. & $\begin{array}{l}\text { I prefer to plan for required pollution control measures in running the agri- } \\
\text { enterprise (-) }\end{array}$ & 2.534* \\
\hline 39. & I prefer to know the transport requirement in running the agri-enterprise & 3.376* \\
\hline
\end{tabular}




\begin{tabular}{|c|c|c|}
\hline 40. & $\begin{array}{l}\text { I prefer to pay little attention to installation capacity of machine in running } \\
\text { the agri-enterprise(-) }\end{array}$ & 3.049: \\
\hline 41. & I prefer to emphasize the product standards in running the agri-enterprise & 1.814: \\
\hline 42. & $\begin{array}{l}\text { I prefer to know the advantage of my product over its substitutes in running the } \\
\text { agri-enterprise }\end{array}$ & 0.221 \\
\hline 43. & $\begin{array}{l}\text { I prefer to experiment with new product distribution channels in running the agri- } \\
\text { enterprise }\end{array}$ & 0.809 \\
\hline 44. & $\begin{array}{l}\text { I prefer less to know the market strategies for sale of product in running the agri- } \\
\text { enterprise(-) }\end{array}$ & 0.199 \\
\hline 45. & $\begin{array}{l}\text { I prefer little to know the nature and size of customer for the product in running } \\
\text { the agri-enterprise(-) }\end{array}$ & 0.534 \\
\hline 46. & $\begin{array}{l}\text { I prefer less to know the prevailing local/national/international trade in running the } \\
\text { enterprise(-) }\end{array}$ & $1.915^{*}$ \\
\hline 47. & $\begin{array}{l}\text { I prefer to know the volume of investment required in running the agri } \\
\text { enterprise }\end{array}$ & 2.238* \\
\hline 48. & $\begin{array}{l}\text { I prefer least to get the profit loss statement prepared in running the agri } \\
\text { enterprise(-) }\end{array}$ & 2.771* \\
\hline 49. & I prefer to know the export potential of my product in running the agri enterprise & 1.032 \\
\hline 50. & $\begin{array}{l}\text { I prefer little to care for research and development strategies in running the } \\
\text { agri enterprise (-) }\end{array}$ & $2.449 *$ \\
\hline 51. & I want to be an elite person in society through agripreneurship & 1.952* \\
\hline 52. & I am ready to invite innovations in agripreneurship & 2.083* \\
\hline 53. & I work hard and smart to make agri enterprise worthy & 1.770* \\
\hline 54. & I can overcome any type of hardships in agri enterprise & 2.024: \\
\hline
\end{tabular}

(-)Indicates negative statements. *Statements which were selected for the study.

SA- Strongly Agree A- Agree UD- Undecided DA- Disagree SDA- Strongly Disagree.

\section{Admimistration of the test}

Each of the thirty six statements were administered to the respondents for studying the attitude of rural youth towards agrienterprises. The score for each individual in the scale was computed by summing up the weights of individual item response. The possible maximum and minimum scores for each respondent was 180 and 36 respectively.

The scale met the reliability and validity test satisfactorily indicated its ability and validity test satisfactorily indicated its ability as an instrument for measuring attitude of rural youth towards agri-enterprises. This study aims at constructing a scale to measure the attitude of rural youth towards agrienterprises.
The affective aspect of attitude scale consisted of 36 items, with high reliability, and more predictive validity. This scale can be used in future studies on perceptions and feeling about the rural youth towards agrienterprises. It will be helpful to the policy makers and administrators to develop suitable coping strategies towards agri-enterprises by knowing the attitude of rural youth towards agri-enterprises.

\section{References}

Chaitanya, K.M.S. 2004. A study on tribal women entrepreneurs in high altitude tribal zone of Andhra Pradesh. Ph.D. Thesis. Acharya N G Ranga Agricultural University, Hyderabad, India.

Chandrakandan, K., Venkatapirabu, J., 
Sekhar, V and Anandakumar, V. 2000. Tests and Measurements in Social Research. APH publishing corporation.

Chave, E.J. 1929. The Measurement of attitude. University of Chicago Press, Chicago.

Edwards, A.L. 1969. Techniques of Attitude Scale Construction. Valkies, Feffer and Simons Pvt. Ltd. Bombay. 149-171.

Edwards, A.L.1957. Techniques of attitude scale construction. Appleton-century crofts, New York.

Goode J.W and Hatt, P.K. 1952. Methods in social research, London, McGraw Hill book company.

Likert, R. 1932. A technique for the measurement of attitude. Archives of Psychology. 140.

New Delhi. 215-234.

Thurstone, L.L. 1946. Comment. American Journal of Sociology. 52: 39-50.

\section{How to cite this article:}

Mubeena, T. Lakshmi, P. L. R. J. Praveena, A. V. Nagavani and Ramana Murthy, B. 2020. Construction of Attitude Scale for Attracting Rural Youth Towards Agri-Enterprises. Int.J.Curr.Microbiol.App.Sci. 9(06): 3106-3111. doi: https://doi.org/10.20546/ijcmas.2020.906.371 